\title{
Lions Bay Noise Mitigation Program
}

\author{
Duane Marriner \\ Wakefield Acoustics Ltd., \#301-2250 Oak Bay Ave., Victoria, B.C., V8R 1G5 \\ duane $a$ wakefieldacoustics.com
}

\begin{abstract}
The Ministry of Transportation (MoT) of the Province of British Columbia (B.C.), Canada, noise abatement policy requires that community noise impacts of highway projects involving new or substantially upgraded highways be assessed and mitigation implemented where warranted. Increasing community demands for noise mitigation, however, may exceed policy standards and pose greater challenges for designers. This paper presents an extraordinary noise model developed to mitigate residential areas of the Village of Lions Bay on the rugged B.C. coastline along the Sea-to-Sky Highway connecting Vancouver, B.C. to Whistler, B.C., Canada home of the Vancouver 2010 Winter Olympic and Para-Olympic Games. The CadnaA Version 3.9.15 software was used to develop a new four-lane split-grade alignment model incorporating two miniinterchanges. With the objective of achieving a $10 \mathrm{dBA}$ noise reduction benefit, mitigation in the form of quiet pavement (OGAFC), traffic calming and 5 meter high sound walls were introduced into the model which included 115 mountain side residential receptors along a $2 \mathrm{~km}$ corridor at elevations of up to 35 meters above the highway. Noise reduction benefits and impacts for dwellings were further analyzed to determine contributions during specific stages of project development by creating a modular, multi-layer noise model of Lions Bay. This work was carried out under the sponsorship of BC MoT.
\end{abstract}

\section{RÉSUMÉ}

Le Ministère de Transport (MoT) de la Province de Colombie Britannique (B.C.), Canada, la politique de diminution de bruit exige que les impacts de bruit de communauté de projets de route aient impliqué nouvel ou substantiellement actualisé les routes sont évaluées et la réduction a exécuté où mérité. La communauté croissante exige pour la réduction de bruit peut dépasser cependant les normes de politique et pose de plus grands défis pour les dessinateurs. Ce papier présente un modèle de bruit extraordinaire a développé pour adoucir des secteurs résidentiels du Village de Baie de Lions sur le robuste B.C. le littoral le long de la Mer-à-la Route de Ciel connecte Vancouver, B.C. à Whistler, B.C.., la maison de Canada du Vancouver 2010 Hiver Jeux Olympiques et Para-Olympiques. Le logiciel de 3.9.15 de Version de CadnaA a été utilisé pour développer un nouveau quatre modèle d'alignement de degré de division d'allée incorpore deux miniéchanges. Avec l'objectif d'atteindre un 10 avantage de réduction de bruit de $\mathrm{dBA}$, la réduction sous forme de trottoir calme (OGAFC), la circulation calmant et 5 mètre hauts murs solides ont été introduits dans le modèle qui a inclus 115 montagne récepteurs résidentielles latérales le long d'un 2 couloir de $\mathrm{km}$ aux élévations de jusqu'à 35 mètres au-dessus de la route. La réduction de bruit profite et influe pour les résidences ont été plus analysé pour déterminer des contributions pendant les étapes spécifiques de développement de projet en créant un modulaire, le modèle de bruit de multi-couche de Baie de Lions. Ce travail a été exécuté sous le sponsorat d'av BC MoT.

\section{INTRODUCTION}

\subsection{Background}

In preparation for the Vancouver 2010 Winter Olympic Games to be held in the resort municipality of Whistler, British Columbia, Canada, the Sea-to-Sky Highway Improvement Project was initiated in 2005. This regional linear-development project reduces travel time along the mountainous coastline from Vancouver to Whistler while enhancing safety to and from the winter venues. The Lions Bay Mitigation Program evolved from a preliminary noise mitigation plan based on the BC MoT Policy [1], which led to a series of public consultations to explore effective and feasible mitigation measures that were supported by residents. This paper presents the modeling techniques used and challenges encountered in achieving the objectives of the program. In addition, the capabilities of the modeling techniques will be displayed.

\subsection{Lions Bay Mitigation Program Objectives}

During the detailed design phase, a four-stage approach to mitigation was proposed. The primary objective of mitigation was to achieve a $5 \mathrm{dBA}$ noise reduction through the use 
of quiet pavement and a speed reduction from 80 to $70 \mathrm{kmph}$. Subsequent stages were to achieve an additional $5 \mathrm{dBA}$ noise reduction through the introduction of a split grade section, sound walls and other barrier enhancements. Priority would be given to fronting residential facades whose noise levels approached or exceeded Leq(24) $55 \mathrm{dBA}$ in the design horizon year.

\subsection{Project Description}

Figure 1.1 provides a view of the new alignment (from the Vancouver end towards Whistler) which shows the final mitigated design with the split grade section in the foreground. The attributes of this alignment and the existing highway through the Lions Bay corridor are as summarized in Table 1.1 .

Figure 1.1 shows that much of the intervening ground between the roadway and the residences was rocky and steep and offered little opportunity for the ground effect to occur. Aged retaining walls were commonly found at the base of the mountain slope and along the lower side of the alignment. The right-of-way (ROW) was moderately forested in most areas.

88 multi-storied residences were included in the core study along the village corridor. Of these, 55 were located at higher elevations on the mountain slope and many had elevated sundeck and patio exposures, typically 25 meters above the roadway. The remaining dwellings were located on the lower side at or below project grade. The mitigation program's objectives were to be achieved at fronting facades on both sides of the alignment.

\section{MODELING METHODOLOGY}

\subsection{Overview}

The noise environment was predicted using computer modeling techniques. A seven-part noise model was developed.

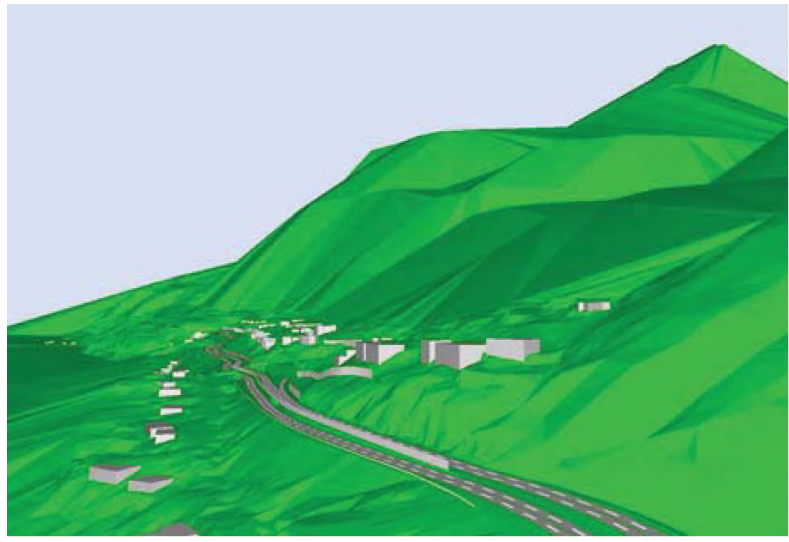

Figure 1.1: View of Sea-to-Sky Highway through Lions Bay from Vancouver End towards Whistler, showing Proposed Four Lane Configuration with $750 \mathrm{~m}$ Split Grade Section.

This multi-layered approach was adopted to project residential noise levels at certain stages during the pre-project, premitigation and the noise mitigation design. Noise reduction benefits and impacts would emerge as changes in residential noise levels as improvements were added. The acoustical modeling software CadnaA Version 3.9.15 was ideally suited for this purpose.

A modular approach was used for improved quality control and assurance. The CadnaA software provided the opportunity of maintaining classes of modeling objects in separate modules that were shared by the models and that could be updated with design changes and other project information.

\subsection{Noise Model}

The attributes of the noise model are listed in Table 2.1. From the first row of the table, the Baseline-Model represents preproject conditions or the existing design in 2004 featuring two lanes of conventional pavement with a posted speed of $80 \mathrm{kmph}$. In the second row, the Base-Model projects the existing design to the design horizon year 2018 (10 years

Table 1.1: Existing and Proposed Alignment through Lions Bay

\begin{tabular}{|c|c|c|}
\hline Attribute & Existing Alignment & Proposed Alignment \\
\hline Lane Configuration & 2 lane standard & 4 lane standard/split grade \\
\hline Pavement Type & Aged Conventional HMA & New OGAFC \\
\hline Average Daily Traffic (vpd)/Year & $\mathbf{1 4 , 3 6 3 / 2 0 0 4}$ & $\mathbf{1 9 , 6 8 0 / 2 0 1 8}$ \\
\hline Average Hourly Traffic (vph)/Year & $\mathbf{5 9 8 / 2 0 0 4}$ & $\mathbf{8 2 0 / 2 0 1 8}$ \\
\hline Day/Night Traffic Split & $\sim 10: 1$ & $\mathbf{3 0} \% \mathbf{2 0 1 8}$ \\
\hline Percent Heavy Vehicles/Year & $\mathbf{2 \% / 2 0 0 4}$ & $\mathbf{7 0}$ \\
\hline Posted Speed (kmph) & $\mathbf{8 0}$ & $<\mathbf{2 \%}$ \\
\hline Highway Grade & $<\mathbf{2 \%}$ & $\mathbf{6 0 - 7 9}$ \\
\hline Elevation (m above Sea Level) & $\mathbf{6 0 - 7 9}$ & $\mathbf{2}$ \\
\hline Length (km) & 2 & $\mathbf{3}$ \\
\hline Sections on Span & 3 & \\
\hline
\end{tabular}


Table 2.1: Noise Model - Mitigation Initiatives Underlined

\begin{tabular}{|c|c|c|c|c|c|c|c|}
\hline Model Name & Alignment & Traffic & Barriers & Pavement/Speed & $\begin{array}{l}\text { Cross } \\
\text { Section }\end{array}$ & $\begin{array}{l}\text { Sound } \\
\text { Walls }\end{array}$ & $\begin{array}{c}\text { Barrier } \\
\text { Enhancemen } \\
\text { ts }\end{array}$ \\
\hline Baseline & $\begin{array}{c}\text { Existing } \\
2 \text { lane }\end{array}$ & 2004 & $\begin{array}{c}\text { Existing } \\
\text { CRB/CMB }\end{array}$ & $\begin{array}{c}\text { Conventional/ } \\
80 \mathrm{kmph}\end{array}$ & $\begin{array}{c}\text { On } \\
\text { grade }\end{array}$ & - & - \\
\hline Base & $\begin{array}{c}\text { Existing } \\
2 \text { lane }\end{array}$ & 2018 & $\begin{array}{c}\text { Existing } \\
\text { CRB/CMB }\end{array}$ & $\begin{array}{c}\text { Conventional/ } \\
80 \mathrm{kmph}\end{array}$ & $\begin{array}{c}\text { On } \\
\text { grade }\end{array}$ & - & - \\
\hline Basic Design & $\begin{array}{l}\text { New } \\
4 \text { lane }\end{array}$ & 2018 & $\begin{array}{c}\text { New } \\
\text { CRB/CMB }\end{array}$ & $\begin{array}{c}\text { Conventional/ } \\
80 \mathrm{kmph} \\
\end{array}$ & $\begin{array}{c}\text { On } \\
\text { grade }\end{array}$ & - & - \\
\hline $\begin{array}{l}\text { First Stage } \\
\text { Mitigation }\end{array}$ & $\begin{array}{l}\text { New } \\
4 \text { lane }\end{array}$ & 2018 & $\begin{array}{c}\text { New } \\
\text { CRB/CMB }\end{array}$ & $\frac{\text { OGAFC }}{70 \mathrm{kmph}}$ & $\begin{array}{c}\text { On } \\
\text { grade }\end{array}$ & - & - \\
\hline $\begin{array}{l}\text { Second Stage } \\
\text { Mitigation }\end{array}$ & $\begin{array}{l}\text { New } \\
4 \text { lane }\end{array}$ & 2018 & $\begin{array}{c}\text { New } \\
\text { CRB/CMB }\end{array}$ & $\begin{array}{l}\text { OGAFC/ } \\
70 \mathrm{kmph}\end{array}$ & $\frac{\text { Split }}{\underline{\underline{\text { grade }}}}$ & - & - \\
\hline $\begin{array}{l}\text { Third Stage } \\
\text { Mitigation }\end{array}$ & $\begin{array}{l}\text { New } \\
4 \text { lane }\end{array}$ & 2018 & $\begin{array}{c}\text { New } \\
\text { CRB/CMB }\end{array}$ & $\begin{array}{l}\text { OGAFC/ } \\
70 \mathrm{kmph}\end{array}$ & $\begin{array}{c}\text { Split } \\
\text { grade }\end{array}$ & $\underline{2.3-5 \mathrm{~m}}$ & - \\
\hline $\begin{array}{c}\text { Fourth Stage } \\
\text { Mitigation }\end{array}$ & $\begin{array}{l}\text { New } \\
4 \text { lane }\end{array}$ & 2018 & $\begin{array}{c}\text { New } \\
\text { CRB/CMB }\end{array}$ & $\begin{array}{l}\text { OGAFC/ } \\
70 \mathrm{kmph}\end{array}$ & $\begin{array}{c}\text { Split } \\
\text { grade }\end{array}$ & $2.3-5 \mathrm{~m}$ & $\underline{1.5-2.5 \mathrm{~m}}$ \\
\hline
\end{tabular}

after project completion as per $\mathrm{BC}$ MoT noise abatement policy). The Base-Model establishes pre-project noise levels with 2018 traffic. In the third row, the Basic Design-Model departs from the existing design with the proposed new fourlane alignment incorporating improved roadside and median safety barriers. In the fourth row, First Stage Mitigation introduces quiet pavement in the form of Open Graded Asphalt Friction Coarse (OGAFC) and a speed reduction from 80 to $70 \mathrm{kmph}$ in order to reduce source emissions. In addition. at this stage, the replacement of a weathered wooden roadside barrier with a new concrete barrier was required. During Second Stage Mitigation a $750 \mathrm{~m}$ long split grade section was proposed at the Vancouver end of the village corridor, to provide additional screening for adjacent residences on both sides of the highway (see Figure 1.1). The split grade face developed a maximum height difference of $2 \mathrm{~m}$ at its midsection. During Third Stage Mitigation, standard concrete sound walls with heights ranging from 2.3 to $5 \mathrm{~m}$ above local ground level were proposed and optimized for location, height and length using CadnaA. All potential locations from the roadside to the ROW were explored. Fourth Stage Mitigation included further barrier enhancements to augment sound walls. Enhancements included, for example, $2.3 \mathrm{~m}$ high roadside barriers on span at the two creek crossings in central Lions Bay.

All models computed first order reflections. The last three models were also run in absorptive mode to assess the advantage of lining vertical screening surfaces with absorptive materials. Such surfaces were numerous and included - existing retaining walls at the base of the mountain slope and along the sides of the creek beds, the split grade face, the mini-change abutments, the sound walls and barrier enhancements.

\section{SUMMARY OF MODELING RESULTS AND INTERPRETATION}

The results from the seven-part noise model are summarized in Figures 3.1 and 3.2 with 2018 Base-Model noise levels in dBA inscribed next to the receptor site numbers. Each series depicted shows the fluctuations in noise benefits and impacts along the corridor during a particular stage of pre-project, pre-mitigation or noise mitigation design. The first of the series, labelled Growth, reflects the $1.6 \mathrm{dBA}$ increase in noise levels at all locations that will accompany traffic growth over the 14 years, 2004 to 2018. The second of the series, labelled Basic Design, indicates the noise benefits/impacts that the pre-mitigation design would bring. In this regard, (see Figure 3.1) 45 of 55 receptors on the mountain slope side would receive either benefits or impacts of less than $1 \mathrm{dBA}$, eight would receive benefits in the range 1 to $3 \mathrm{dBA}$ and two would receive impacts in the range 1 to $1.6 \mathrm{dBA}$.

The origins of these effects are revealed in the accompanying $3 \mathrm{D}$ visualizations taken from the perspective of the receptor sites. For example, the $1.1 \mathrm{dBA}$ benefit at Site 41 is attributed to a decrease in this receptor's exposure resulting from the displacement of the near lane to a location under the top-ofcut that provides increased screening (see Figures 3.3a and b). By contrast, the impact at Site 14 of $1.6 \mathrm{dBA}$ is attributed to increased exposure from the widening of the highway, as evident when Figures 3.4a and $b$ are compared. This effect is also seen at Site 26 to a lesser degree.

Figure 3.2 shows that for the majority of receptors on the lower side, the basic design would provide noise reduction benefits - a trend that is primarily due to design features including decreases in exposure resulting from the widening/ 


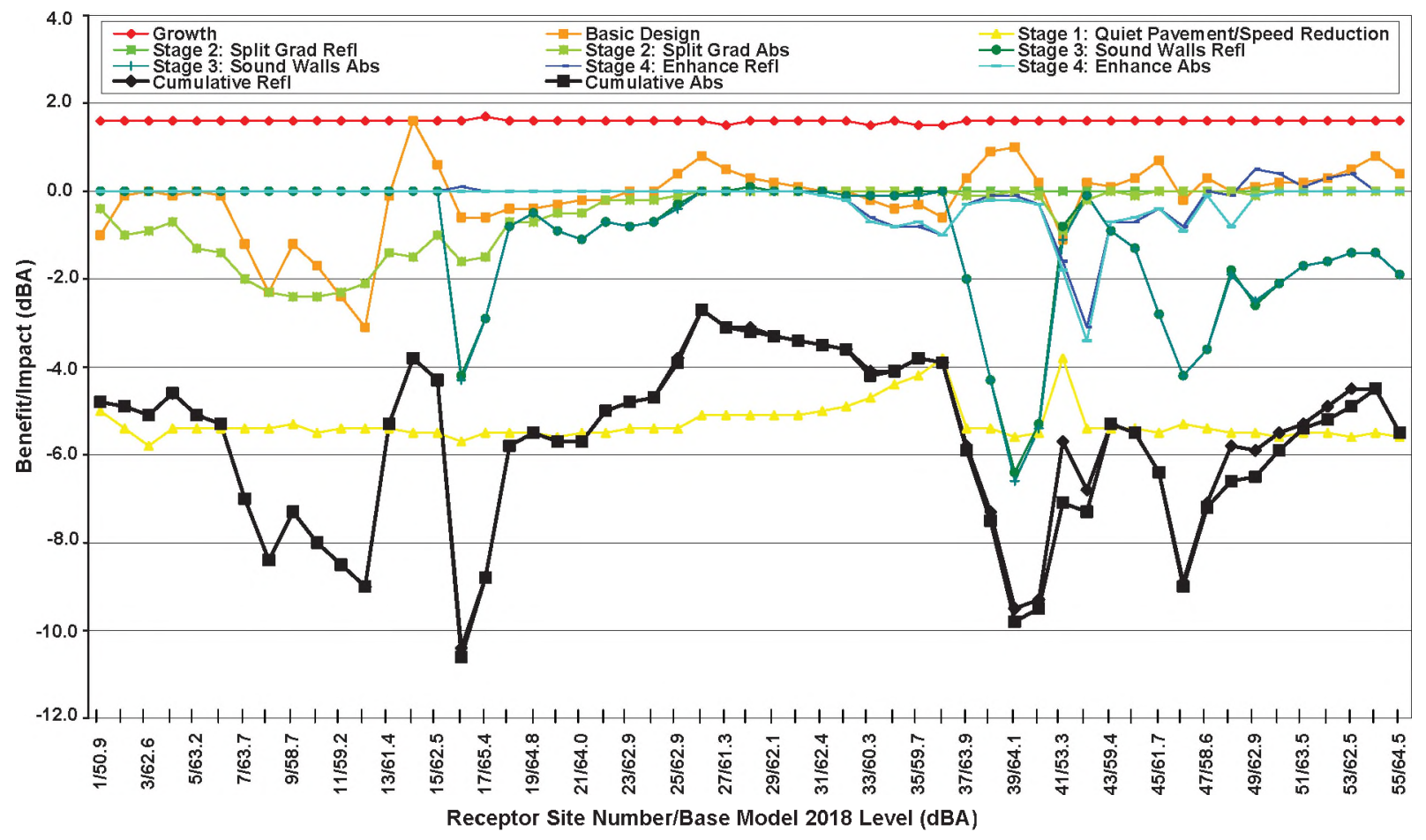

Figure 3.1: Noise Benefit/Impact vs Residential Site Number - Higher Side on Mountain Slope

realignment and increased screening from improved roadside barriers mounted on lower side retaining walls.

The Quiet Pavement/Speed Reduction series of Figures 3.1 and 3.2 exhibit the relatively consistent mitigation effect that the first stage of mitigation would provide; that is noise reduction benefits in the range of 4 to $5 \mathrm{dBA}$ at fronting residential facades on both sides. Fluctuations are believed to be due to the interactions involving the altered source spectra from tires on OGAFC at a reduced speed and screening along

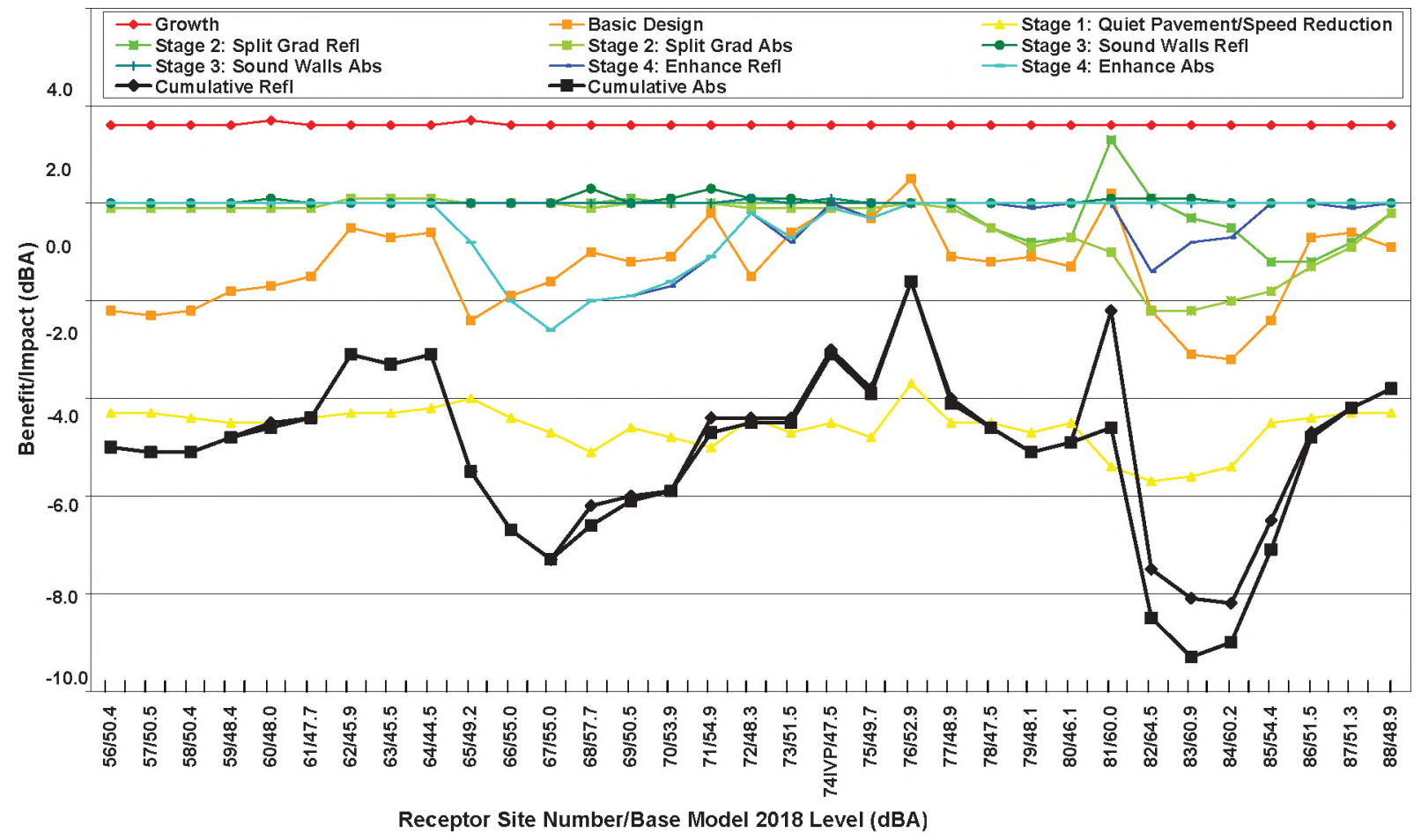

Figure 3.2: Noise Benefit/Impact vs Residential Site Number - Lower Side 


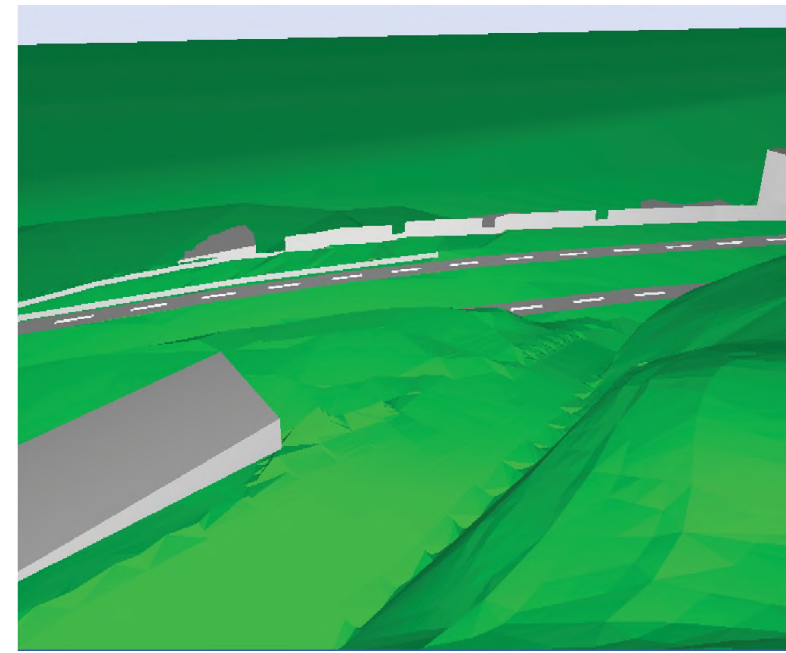

Figure 3.4a: View from Site 43 from Base Model Existing

Two Lane Configuration showing Screening of Near

Lane by Top-of-Cut and the Details of a Weathered

Wooden Fence to be Replaced under Stage 1 Mitigation.

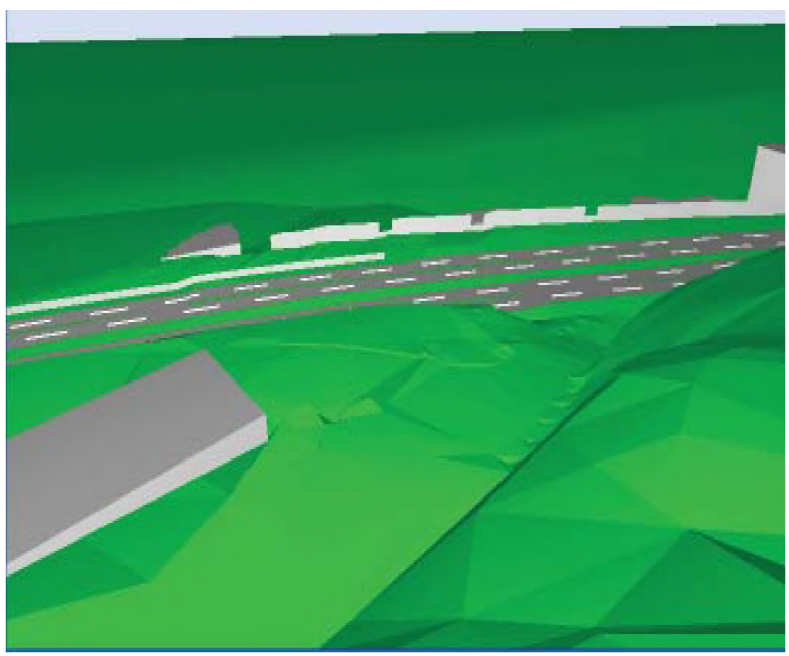

Figure 3.3b: View of Site $\mathbf{4 3}$ depicting Project Benefit from Basic Design Model due to a Further Displacement of the Near Lane under the Top-of-Cut.

the noise propagation path.

The two Split Grade series of Figure 3.1 indicate that with either reflective or absorptive screening, the $750 \mathrm{~m}$ long split grade section incorporating a $2 \mathrm{~m}$ high face and $1.5 \mathrm{~m}$ high median barrier provided benefits up to $2.4 \mathrm{dBA}$ for receptors located on elevated sundecks on the mountain slope. The split grade design also provided benefits up to $1.2 \mathrm{dBA}$ (see Figure 3.2) for receptors located on the lower side if the median barrier, split grade face and mini-change abutment were reflective and $2.2 \mathrm{dBA}$ if these vertical surfaces were absorptive.

The two Sound Wall series in Figure 3.1 show the effectiveness of third stage mitigation. Due to cost, sound walls were only proposed for mountain slope residences with greater exposures. However, due to the substantial receptor heights involved in some residential areas, $5 \mathrm{~m}$ high sound walls were deemed ineffective (see Figure 3.5). In other areas, CadnaA 23 - Vol. 38 No. 1 (2010)

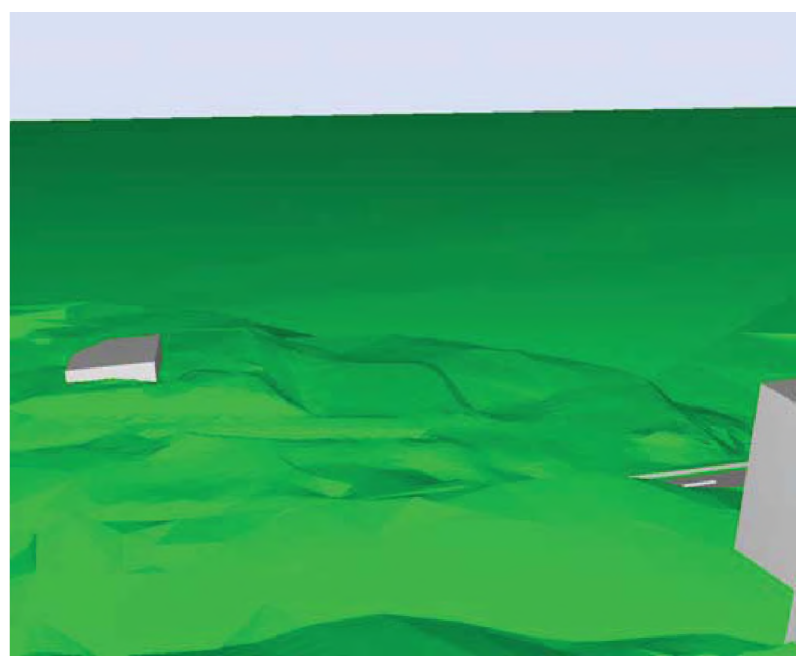

Figure 3.4a: View from Sundeck of Site 14 overlooking Existing Alignment tow ard Green Ocean and Blue Sky from Base Model (Existing Two Lane Configuration).

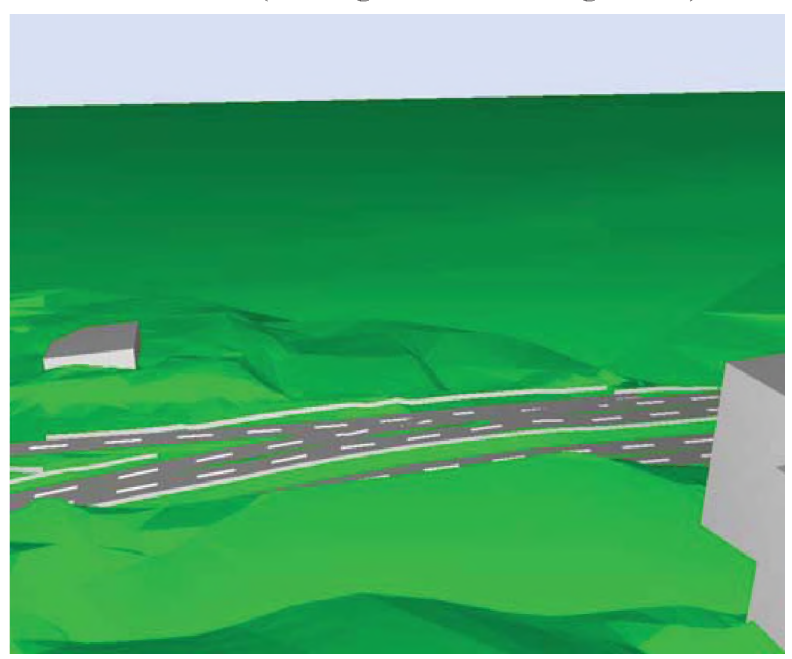

Figure 3.4b: View from Site 14 depicting Project Impact from Basic Design Model (Four Lane Configuration).

predicted that reflective sound walls would provide benefits starting at $1 \mathrm{dBA}$ up to $6.4 \mathrm{dBA}$ with absorptive sound walls providing up to $6.6 \mathrm{dBA}$

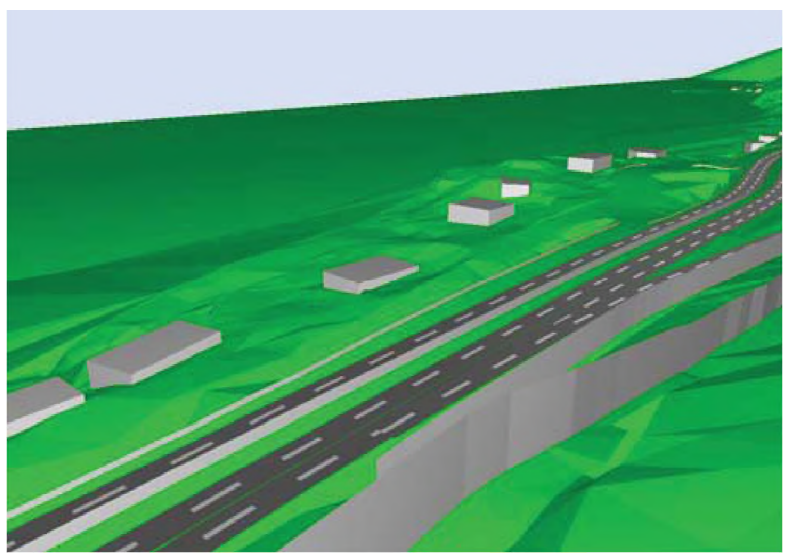

Figure 3.5: View from Sundeck of Site 5 depicting Two Ineffective Sound Wall Options on the Right Hand Side and the $1.5 \mathrm{~m}$ High Split Grade Median Barrier (Four Lane Configuration).

Canadian Acoustics / Acoustique canadienne 
The two Enhancement series exhibit the effectiveness of the fourth and final stage of mitigation. The enhancements included lower profile barriers proposed in strategic locations on either side of the alignment. For example, a reduced $2.3 \mathrm{~m}$ high barrier-on-span was proposed to screen emissions from creek bridge decks that were known to limit the effectiveness of the higher sound walls. A $2.3 \mathrm{~m}$ high barrier was also proposed at a key location along the propagation path between the split grade face/mini-change abutment to exposed receptors at grade on the lower side. The purpose of this barrier enhancement was to screen reflections from these vertical surfaces and was therefore not relevant in the absorptive case.

The two-bolded series in Figures 3.1 and 3.2 obtained by adding the benefits/impacts on a site-by-site basis indicated the cumulative effects of the pre-project, pre-mitigation and four-stage mitigation design. It may be seen from the Figure 3.1 series that the mitigation program's primary objective of achieving an initial $5 \mathrm{dBA}$ noise reduction was met or exceeded at numerous receptor locations on the mountain slope except where there were substantial impacts from the widening and realignment. The Figure 3.2 series shows that receptors on the lower side that did not receive a $5 \mathrm{dBA}$ noise reduction had base (2018) noise levels that were substantially below Leq(24) $55 \mathrm{dBA}$.

\section{CONCLUSIONS}

The Lions Bay Mitigation Program was shown to reduce 2018 traffic noise levels by at least $4.5 \mathrm{dBA}$ for 41 of the mountain slope residences and by at least $6 \mathrm{dBA}$ for the majority of residences on the lower side with base (2018) levels approaching or exceeding Leq(24) $55 \mathrm{dBA}$.

While the primary objective of achieving an initial $5 \mathrm{dBA}$ noise reduction was substantially attained, the overall objective of a $10 \mathrm{dBA}$ noise reduction could not be met consistently along the project corridor although it was approached at 9 locations on the mountain slope where noise levels were reduced by $8 \mathrm{dBA}$ or more.

The multi-layered modeling technique together with the visualization features of Cadna $\mathrm{A}$ made it possible to diagnose the origins of noise benefits/impacts from the basic pre-mitigation design through the four staged mitigation design down a corridor, which included complex source/receiver geometry. With the visualization features of CadnaA it was possible to confirm that it would not be possible to achieve noise reductions over $5 \mathrm{dBA}$ at many mountain slope locations without considering sound wall heights in excess of $5 \mathrm{~m}$.

\section{ACKNOWLEDGMENTS}

The author gratefully acknowledges the support and guidance of the Province of British Columbia, Canada, Ministry of Transportation.

\section{REFERENCES}

[1] "Revised Policy For Mitigating the Effects of Traffic Noise from Freeways and Expressways", Province of British Columbia Ministry of Transportation and Highways - Highway Environment Branch, (1993). 

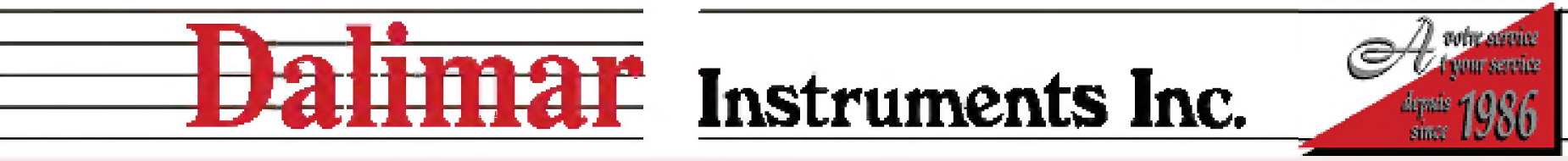

\section{ACOUSTIC SOLUTIONS}

\section{Hand held meters}

- Noise dosimeters

- Sound level meters (Class 1 or 2)

- Sound level meters with real time filters (1/1 and 1/3 octave)

- Noise exposure analysis software
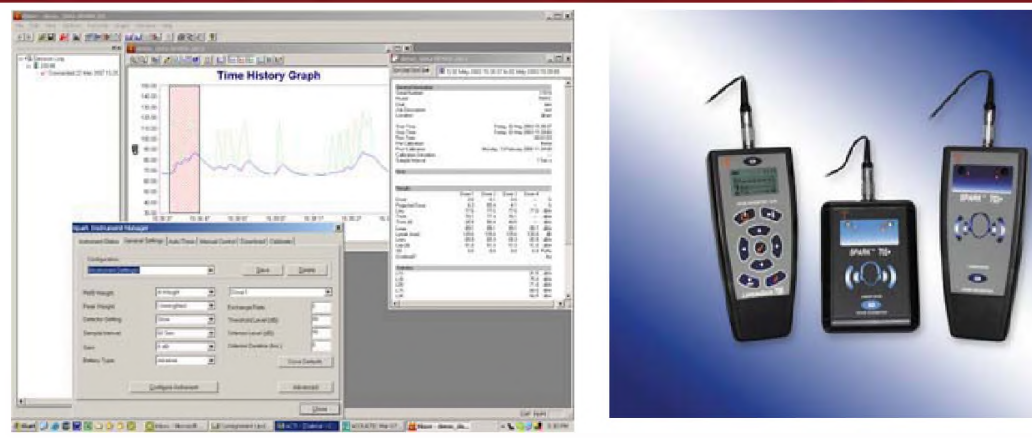

\section{Permanent and semi-permanent systems}

- Sound level meters / real time analyzers

- $1 / 1$ and 1/3 real time analysis with audio recording

- Automatic storage of data

- Stand alone systems with remote communication capabilities

\section{Multi-purpose analyzers}

- Frequency analyzer (portable and multi-channel)

- Sound power $\&$ acoustic intensity measurements

- Audiometer calibration systems

\section{Rental services}

- Rental of a wide range of meters and systems for noise $\&$ vibration measurements

\section{Related accessories}
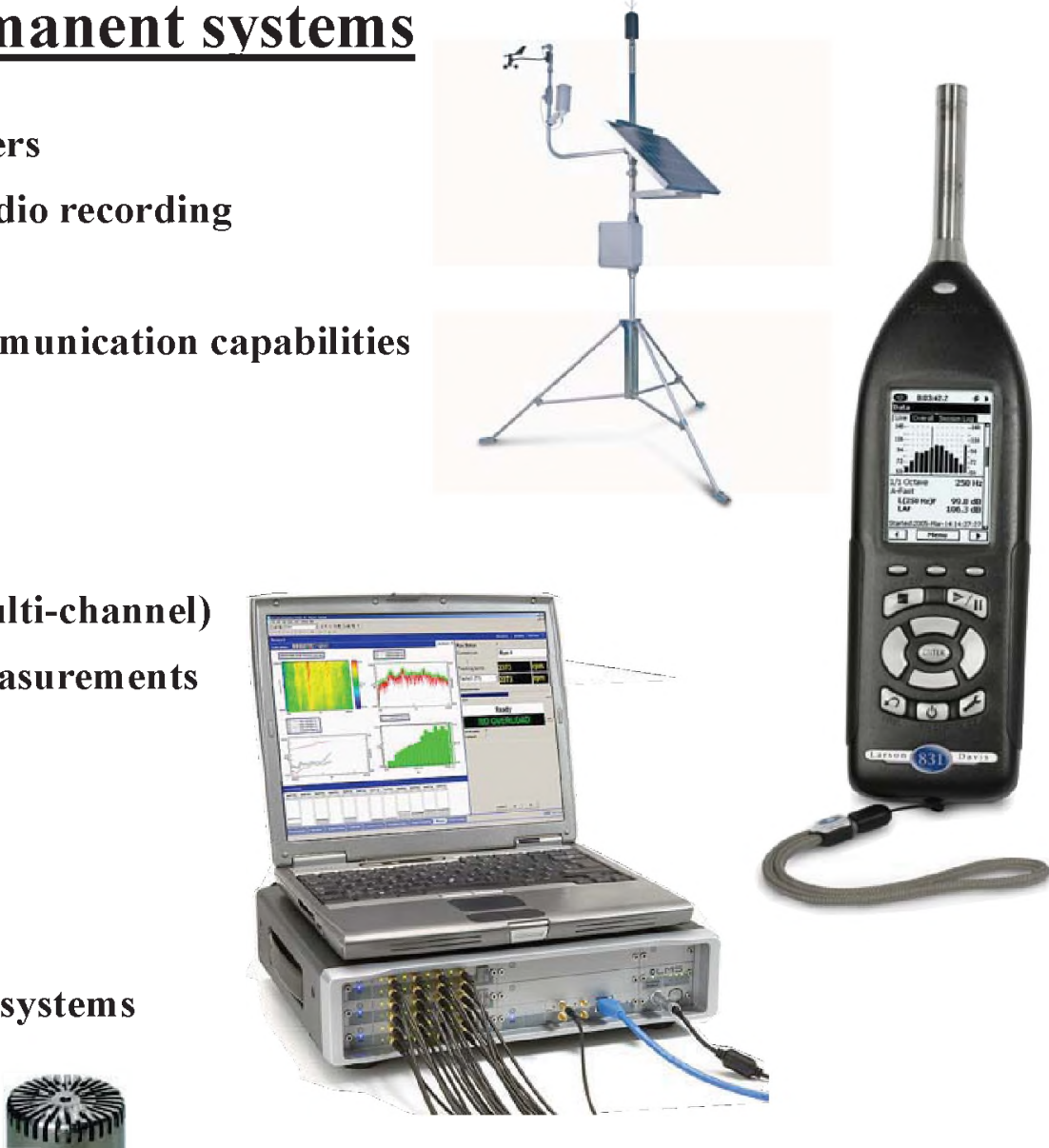

Analysis software, microphones, calibrators, cables, etc...

$$
\text { QC: 450-424-0033, ON: 905-707-9000, AB: 403-288-4416 }
$$




\section{GOAL:}

\section{$\checkmark$ REDUCE NOISE}

$\checkmark$ REDUCE WEIGHT

$\checkmark$ REDUCE COST

$\checkmark$ INCREASE CUSTOMER PROFITS

\section{GOAL ACHIEVED.}

Blachford specializes in testing, designing and producing quality acoustical materials.

Strategic, fast, flexible and loaded with talent, we bring our customers big-impact solutions. We're a responsive, reliable partner fully committed to continual improvement and well-known for our strengths in technology, innovation and rigorous process.

In the past three years we've saved our customers millions in both costs and in pounds of excess weight. And we've reduced product noise levels an average of $38 \%$. That's something to celebrate.
Featuring state-of-the-art resources and expertise, Blachford is your ideal partner for producing noise control products while improving your bottom line.

Quality Management System ISO 9001:2000 \& ISO/TS 16949

Environmental Management System Responsible Care (CDN) \& ISO 14001 (US) ISO 17025 for ASTM C423 \& SAE J1400
- Engineering

- Designing

- Testing

- Manufacturing

For details call

630.231 .8300 or visit us at blachford.com

Blachford 

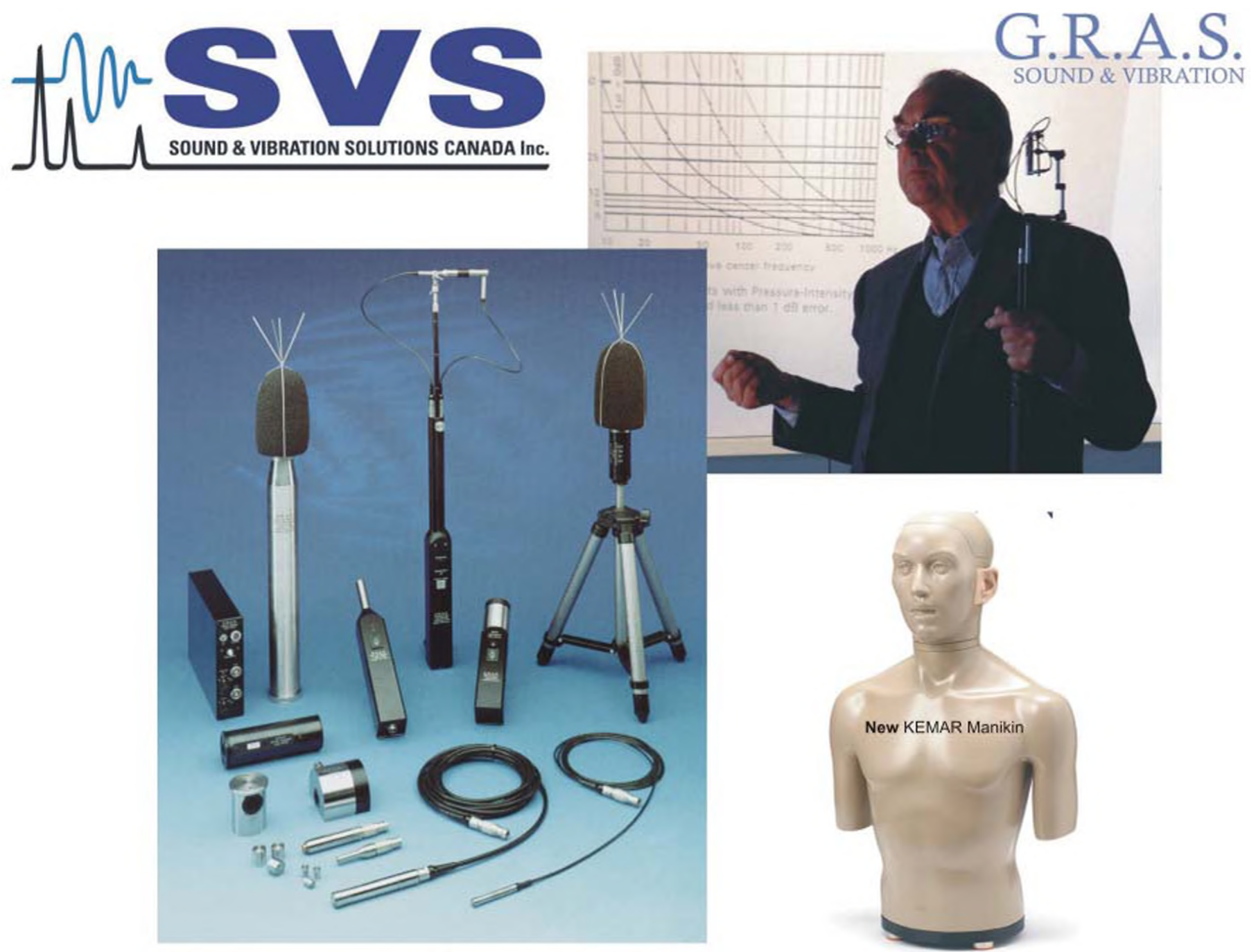

\section{Integrated Solutions from World Leaders}

Precision Measurement Microphones

Intensity Probes

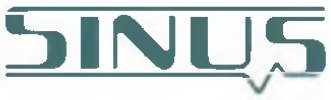

Outdoor Microphones

Sound Level Meters Type I

Ear Simulation Devices

Speech Simulation Devices

Calibrators

Array Microphones

Sound Quality

Sound Intensity

Sound Power

Room Acoustics

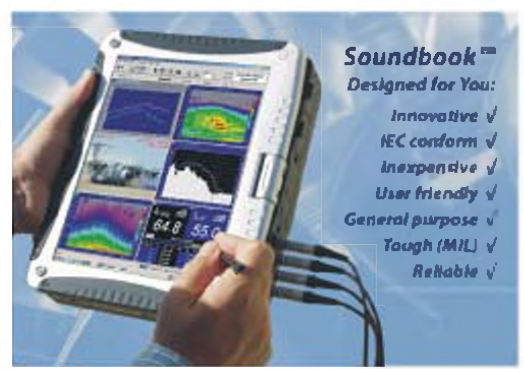

G.R.A.S.

SOUND \& VIBRATION

Noise Monitoring

Dynamic Signal Analyzers

Multi-Channel Dynamic Analyzer/Recorders

Electro Dynamic Shaker Systems

Advanced Sound \& Vibration Level Meters

Doppler Laser Optical Transducers (Laser Vibrometers)

519-853-4495

Sound \& Vibration Solutions Canada Inc. andy @svscanada.ca www.svscanada.ca 